\title{
Is Current Social Distancing Enough?
}

\author{
Sasa Kenjeres, ${ }^{1}$ Frank S. Henry, ${ }^{2}$ and Akira Tsuda (i) ${ }^{3}$ \\ ${ }^{1}$ Department of Chemical Engineering, Faculty of Applied Sciences, Delft University of Technology, 2629 HZ Delft, The \\ Netherlands; ${ }^{2}$ Department of Mechanical Engineering, Manhattan College, Riverdale, NY 10471, USA; and ${ }^{3}$ Tsuda Lung \\ Research, Shrewsbury, MA 01545, USA
}

(Received 2 October 2020; published online 11 February 2021)

To the editor,

The separation distance recommended ${ }^{2}$ to lower the risk of being infected by SARS COV-2 virions via airborne transmission ${ }^{3}$ appears to be largely based on data from large-droplet experiments in quiescent environments. ${ }^{6}$ Here, we investigate how far exhaled airflow during normal speech can transport smaller particles ${ }^{5}$ into quiescent air and into an environment with ambient air motion.

We modeled expiratory flow during normal conversational speech as a jet of constant velocity of $1 \mathrm{~m} / \mathrm{s}$ and $10 \mathrm{~s}$ in duration ${ }^{4}$ through an elliptical orifice. We seeded the expiratory airflow with SARS COV-2 droplet nuclei $\left(\approx 4 \mu \mathrm{m}\right.$ in diameter $\left.{ }^{5}\right)$ and considered the jet's development in quiescent air (Fig. 1a) and in an environment with a low-speed tailwind ${ }^{1}$ (Fig. 1b). In both cases, the simulation showed that while the jet was smooth, axisymmetric, and fully laminar at the mouth, it eventually became unstable and turbulent; however, significant differences in the details of the flows are evident. In the quiescent case, transition occurred a few orifice diameters from the mouth, and once turbulent, further forward motion of the jet was impeded (Fig. 1a). In the tailwind case, the laminar region persisted much longer, and the turbulent cloud was transported farther by the ambient air motion (Fig. 1b). (also, please see accompanied animations.)

While the quiescent case (Fig. 1a) supports the social distancing recommendation of six feet ${ }^{2}(\approx 1.8 \mathrm{~m})$, much caution should be applied. In practice, the air is unlikely to be still, and our investigation reveals that the reach of the virus-laden ${ }^{3}$ exhaled air is strongly influenced by the ambient airflow. Also, we modeled normal speech (with $\sim 1 \mathrm{~m} / \mathrm{s}$ expiratory flow rate) but the further people are from each other, the louder they tend to speak. Speaking more loudly or choiring results in an increase in both exhaled and inhaled air volume, and both could promote an increase in virus transmission. $^{3}$

It is also important to differentiate between outside and indoor gathering. Although it is likely that any virus-laden ${ }^{3}$ exhaled air is quickly diluted by the ambient air in the case of outside gatherings, indoor gatherings could be fertile grounds for virus transmission. We conclude that the distance virus-laden ${ }^{3}$ exhaled air travels during speech depends strongly on the motion of the ambient air. While the ambient air motion considered here would be barely perceptible, ${ }^{1}$ we have shown that even this small air current can double the reach of the virus-laden ${ }^{3}$ air.

Address correspondence to Sasa Kenjeres, Department of Chemical Engineering, Faculty of Applied Sciences, Delft University of Technology, 2629 HZ Delft, The Netherlands. Electronic mail: S. Kenjeres@tudelft.nl Akira Tsuda, Tsuda Lung Research, Shrewsbury, MA 01545, USA. Electronic mail: atsuda@hsph.harvard.edu 


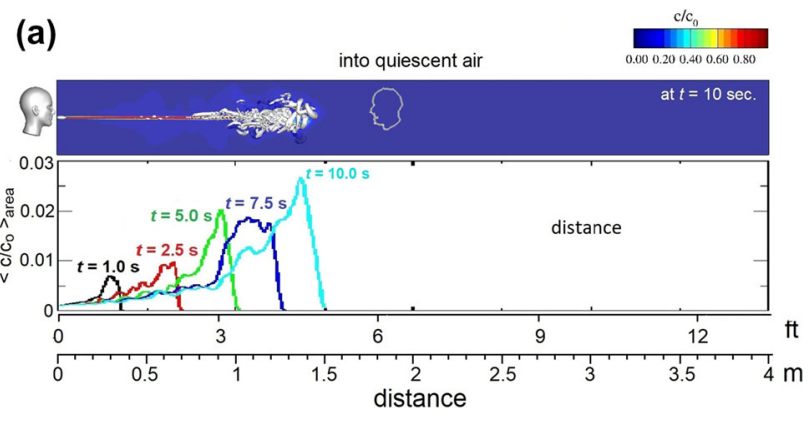

(b)

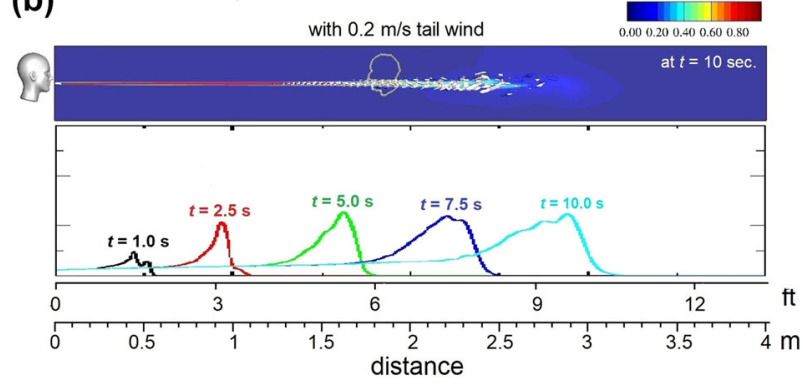

FIGURE 1. The trajectory of virus-laden ${ }^{3}$ exhaled air while speaking for $10 \mathrm{~s}$ in two different environments (quiescent air vs. a low-speed tailwind). The grayscale, cloud-like, structures shown in the upper panels denote eddy structures/local vortical flow structures, and the color-maps shown in the lower panels give the local cross-sectional average concentration $\left(c / c_{0}\right.$; where $c_{0}$ is the concentration at the mouth) over time in the central vertical plane. Respiration physiology during speaking is different from that of tidal breathing. Inspiration vs. expiration ratio is about 1:9, instead of approximately 1:1 during normal breathing. After a rapid inhalation of air, the lung volume (usually $\sim 35 \%$ of vital capacity) decreases nearly linearly during speech. A linear decrease of lung volume implies a constant expiratory flow. A mouth opening was modeled as an orifice of elliptic shape, whose area is $\sim 1.8 \mathrm{~cm}^{2}$ (an average value for an adult) with an aspect ratio of 0.6 . This results an orifice flow rate of $1 \mathrm{~m} / \mathrm{s}$. We simulated the flow and local concentration of droplets using Large Eddy Simulation (LES), which is based on solving discretized forms of conservation of mass, momentum and concentration of species (Eulerian approach, with 2nd order accurate finite-volume based TU Delft in-house computer code). The entire simulation domain is represented by approximately 4 million ( $\mathrm{Nx}: \mathrm{Ny}: \mathrm{Nz}=402: 102: 102$ ) nonuniformly distributed hexagonal control volumes covering a total simulation domain of $4.0 \times 0.42 \times 0.42 \mathrm{~m}^{3}$. The simulation time-step was $0.01 \mathrm{~s}$.

\section{SUPPLEMENTARY INFORMATION}

The online version of this article (https://doi.org/10. 1007/s10439-021-02741-y) contains supplementary material, which is available to authorized users.

\section{FUNDING}

All authors state no financial association on this work.

\section{OPEN ACCESS}

This article is licensed under a Creative Commons Attribution 4.0 International License, which permits use, sharing, adaptation, distribution and reproduction in any medium or format, as long as you give appropriate credit to the original author(s) and the source, provide a link to the Creative Commons licence, and indicate if changes were made. The images or other third party material in this article are included in the article's Creative Commons licence, unless indicated otherwise in a credit line to the material. If material is not included in the article's Creative Commons licence and your intended use is not permitted by statutory regulation or exceeds the permitted use, you will need to obtain permission directly from the copyright holder. To view a copy of this licence, visit http://crea tivecommons.org/licenses/by/4.0/.

\section{REFERENCES}

${ }^{1}$ ANSI/ASHRAE Standard 55-2017 - Thermal Environmental Conditions for Human Occupancy.

${ }^{2}$ Centers for Disease Control (CDC). 2020 CDC Guidelines on Social Distancing. https://www.cdc.gov/coronavirus/201 9-ncov/prevent-getting-sick/social-distancing.html.

${ }^{3}$ Centers for Disease Control (CDC). Scientific Brief: SARSCoV-2 and Potential Airborne Transmission. https://www. cdc.gov/coronavirus/2019-ncov/more/scientific-brief-sars-co v-2.html.

${ }^{4}$ Fuchs, S., U. D. Reichel, and A. Rochet-Capellan. Changes in speech and breathing rate while speaking and biking. $18^{\text {th }}$ Int'l. Cong. Phonet. Sci., Glasgow, United Kingdom, 2015. https://doi.org/10.5282/ubm/epub.25254https://doi.org/10.5 282/ubm/epub.25254.

${ }^{5}$ Stadnytskyia, V., C. E. Baxb, A. Baxa, and P. Anfinrud. The airborne lifetime of small speech droplets and their potential importance in SARS-CoV-2 transmission. Proc. Natl. Acad. Sci. USA 117(22):11875-11877, 2020.

${ }^{6}$ Wells, W. F. On air-borne infections: study II. Droplets and droplet nuclei. Am. J. Epidemiol. 20(3):611-618, 1934.

Publisher's Note Springer Nature remains neutral with regard to jurisdictional claims in published maps and institutional affiliations. 